CZASOPISMO INŻYNIERII LA¿OWEJ, ŚRODOWISKA I ARCHITEKTURY JOURNAL OF CIVIL ENGINEERING, ENVIRONMENT AND ARCHITECTURE

JCEEA, t. XXXIII, z. 63 (2/I/16), kwiecień-czerwiec 2016, s. 7-20

\author{
Mariusz BARSZCZ ${ }^{1}$ \\ Zbigniew BARTOSIK ${ }^{2}$ \\ Sylwester RUKŚĆ ${ }^{3}$ \\ Jakub BATORY ${ }^{4}$
}

\title{
OBLICZENIE PRZEPEYWÓW MAKSYMALNYCH I ICH REDUKCJI W ZLEWNI ZURBANIZOWANEJ
}

\begin{abstract}
W pracy przedstawiono wyniki zastosowania modelu SWMM do obliczenia przepływów o prawdopodobieństwach 50, 10, 2 i $1 \%$ w 8. przekrojach Potoku Służewieckiego na odcinku od km 0+000 do 6+576 oraz w 2. przekrojach Rowu Wolica. Zlewnia Potoku Służewieckiego jest zlokalizowana w południowej części Warszawy. Największe zagrożenie powodziowe występuje na odcinku Potoku Służewieckiego od km 0+000 do 3+875. Przepustowość koryta Potoku na tym odcinku kształtuje się na poziomie przepływu maksymalnego o prawdopodobieństwie 50\%. Największe wartości przepływów w Potoku Służewieckim prognozowano w przekroju obliczeniowym numer V (km 4+267): $\mathrm{Q}_{50 \%}=13,863, \mathrm{Q}_{10 \%}=23,019$, $\mathrm{Q}_{2 \%}=28,825 \mathrm{i} \mathrm{Q}_{1 \%}=30,500 \mathrm{~m}^{3} \cdot \mathrm{s}^{-1}$. Jedną z przyczyn występowania zagrożenia powodziowego w dolnym biegu Potoku Służewieckiego jest dopływ dużej ilości wód opadowych Rowem Wolica. Wartości przepływów w górnym odcinku Rowu Wolica (w przekroju VI) zawierały się w granicach od 8,005 do $12,402 \mathrm{~m}^{3} \cdot \mathrm{s}^{-1}$, w zależności od prawdopodobieństwa wystąpienia opadu obliczeniowego. W celu określenia możliwości redukcji przepływów w Rowie Wolica, przeprowadzono obliczenia w których uwzględniono zastosowanie kryzy na odcinku ujściowym kolektora do kanału otwartego. Zastosowanie kryzy w kolektorze pozwoli zredukować przepływy o prawdopodobieństwach 50, 10 i $2 \%$ odpowiednio o 61,$0 ; 46,0$ i 36,6\%. Zastosowanie kryzy o stałej średnicy $\phi 1,08 \mathrm{~m}$, ustalonej dla przepływu o prawdopodobieństwie $2 \%$, spowoduje znacznie mniejszą redukcję przepływów maksymalnych o prawdopodobieństwach 50 i $10 \%$.
\end{abstract}

Słowa kluczowe: zlewnia zurbanizowana, model SWMM, przepływy maksymalne, zagrożenie powodziowe, redukcja przepływów

\footnotetext{
${ }^{1}$ Autor do korespondencji/corresponding author: Mariusz Barszcz, Szkoła Główna Gospodarstwa Wiejskiego w Warszawie, Katedra Inżynierii Wodnej, ul. Nowoursynowska 159, 00-787 Warszawa, tel. 22 5935284, mariusz_barszcz@sggw.pl

2 Zbigniew Bartosik, Specjalistyczna Pracownia Projektowa „WAGA-BART”, Warszawa

${ }^{3}$ Sylwester Rukść, Specjalistyczna Pracownia Projektowa „WAGA-BART”, Warszawa

4 Jakub Batory, Specjalistyczna Pracownia Projektowa „WAGA-BART”, Warszawa
} 


\section{Wprowadzenie}

W artykule przedstawiono wyniki obliczeń przepływów o prawdopodobieństwach przekroczenia 50,10, 2 i $1 \%$ w dziesięciu przekrojach obliczeniowych (w 8. przekrojach Potoku Służewieckiego oraz w 2. przekrojach Rowu Wolica będącego dopływem Potoku), które przeprowadzono za pomocą modelu SWMM (Storm Water Management Model). Model SWMM jest przeznaczony do symulacji odpływu wód w zlewniach miejskich w reakcji na pojedyncze lub ciągłe zdarzenia opadowe. Parametry modelu są fizycznie mierzalnymi charakterystykami zlewni i aktualnych warunków hydrometeorologicznych. SWMM jest złożonym modelem dynamicznym o znanej strukturze wewnętrznej (model „białej skrzynki”), o parametrach przestrzennie rozłożonych. Procedura obliczeniowa modelu bazuje na zbiorze zlewni cząstkowych z określonymi atrybutami, które transformują spadający na ich powierzchnię opad w odpływ. Powstający odpływ jest transportowany do profilu zamykającego zlewnię poprzez system hydrauliczny zlewni, który składa się z przewodów sieci kanalizacyjnej, kanałów otwartych, zbiorników retencyjnych, przepustów, pomp i regulatorów przepływu (takich jak zastawki, zwężki, itd.). W pracy zamieszczono również wyniki analizy, przeprowadzonej za pomocą modelu SWMM, która dotyczyła możliwości redukcji przepływów w Rowie Wolica za pomocą kryzy umieszczonej w kolektorze, w miejscu tuż powyżej wylotu kolektora do kanału otwartego. Przedstawione analizy zostały uwzględnione w koncepcji pt. ,Przebudowa układu hydrologicznego obejmującego Potok Służewiecki i Rów Wolica w celu zabezpieczenia przeciwpowodziowego rejonu dolnego biegu Potoku Służewieckiego" [8].

\section{Opis badanej zlewni}

Na rys. 1 przedstawiono zlewnię Potoku Służewieckiego, zlokalizowaną w południowej części Warszawy. Powierzchnia badanej zlewni do ujścia w Jez. Wilanowskim wynosi 55,2 $\mathrm{km}^{2}$. W górnej części zlewni Potok Służewiecki jest kanałem zamkniętym - do miejsca poniżej portu lotniczego „Okęcie”. Jego głównymi dopływami są Rów Grabowski i Rów Wolica. Drugi z wymienionych cieków jest zasilany wodami opadowymi odprowadzanymi za pomocą kanalizacji deszczowej ze zlewni o powierzchni $6,23 \mathrm{~km}^{2}$. Na rys. 1 przedstawiono również lokalizację skrajnych przekrojów obliczeniowych, stanowiących początek i koniec badanego odcinka Potoku Służewieckiego (od km 0+000 do 6+576), jak również lokalizację głównych posterunków pomiarowych.

Posterunki wodowskazowe i opadowe (poza jednym opadowym „Okęcie”) zainstalowano w ramach projektu badawczego COST/210/2006. Hydrogramy stanów wody (później przeliczane na przepływy) i wysokości opadów były rejestrowane za pomocą elektronicznych urządzeń w przyjętych 10 . minutowych przedziałach czasowych. Na rys. 2 przedstawiono widoki dwóch profili wodowskazowych w badanej zlewni. 


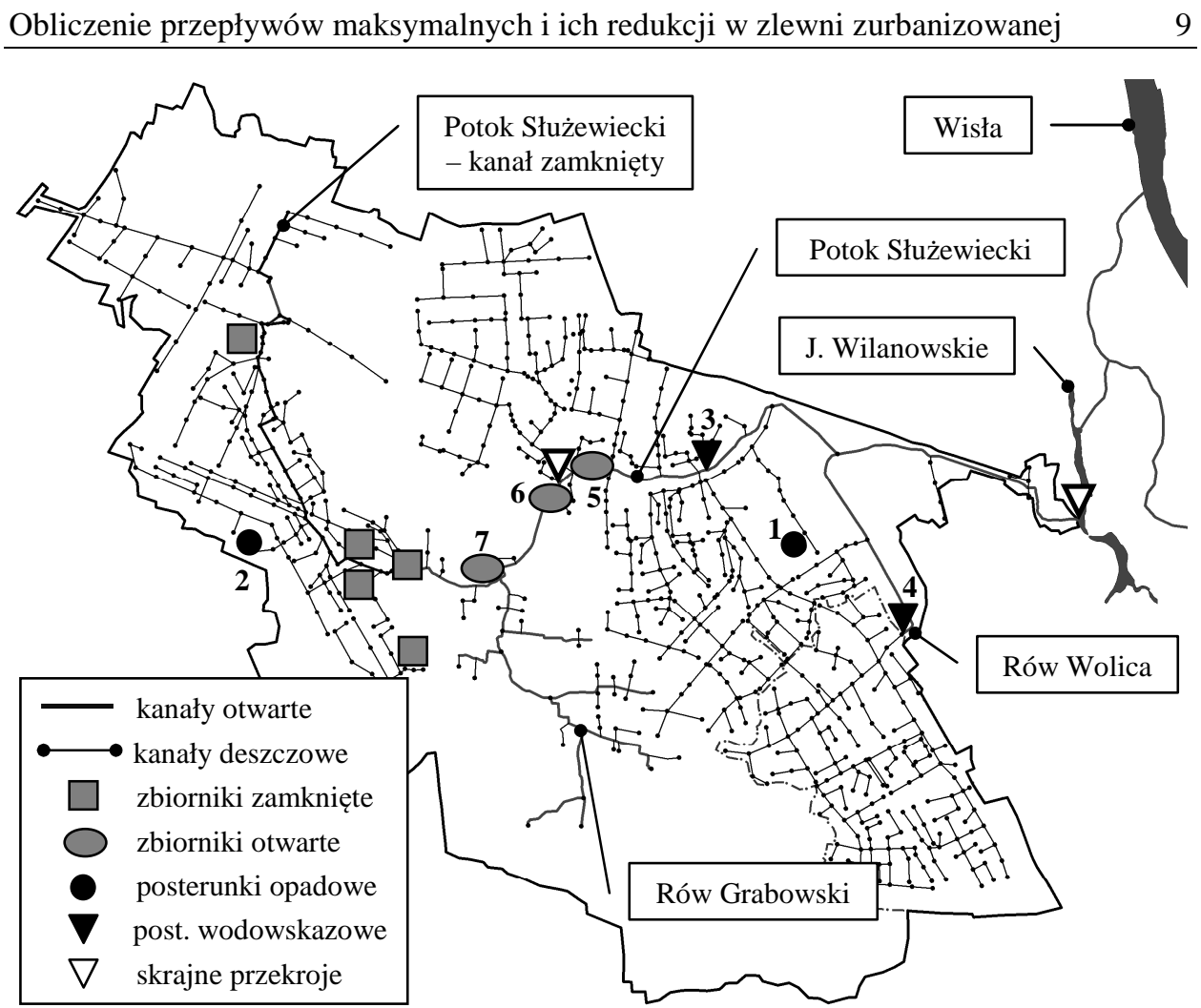

Rys. 1. System odprowadzania wód opadowych w zlewni Potoku Służewieckiego

Fig. 1. Rainwater drainage system in the Służewiecki Stream catchment

Objaśnienia / Explanations: Posterunki opadowe i wodowskazowe / Rainfall and water gauge stations: 1 - SGGW, 2 - Okęcie, 3 - Rosoła, 4 - Płaskowicka; Zbiorniki otwarte/ Reservoirs: 5 - Staw Służewiecki, 6 - Staw Wyścigi, 7 - Staw Berensewicza
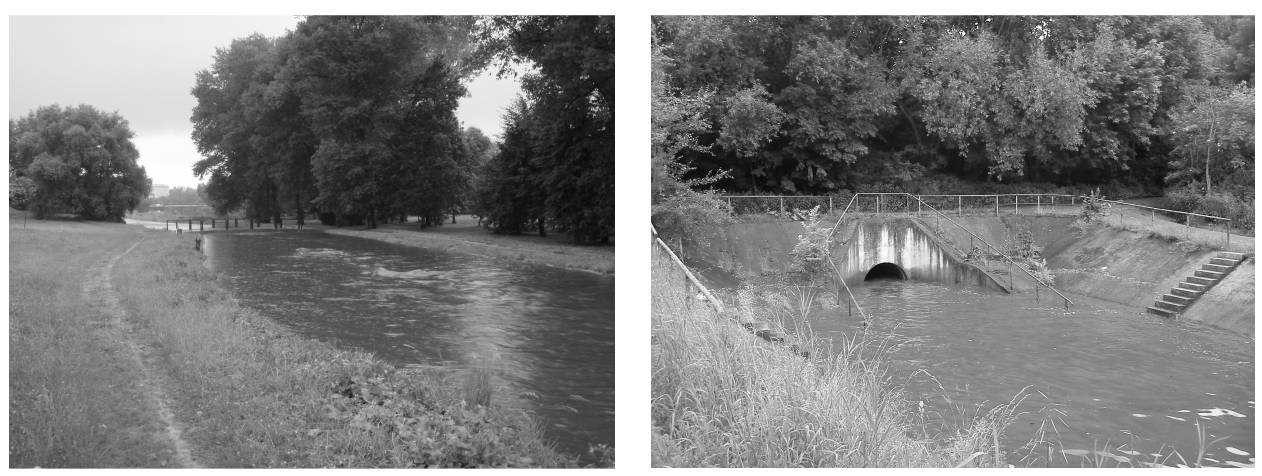

Rys. 2. Profile wodowskazowe „Rosoła” i „Płaskowicka” (foto: M. Barszcz)

Fig. 2. The water gauge station of "Rosoła" and "Płaskowicka" 


\section{Model zlewni Potoku Służewieckiego}

Do obliczania przepływów o określonym prawdopodobieństwie przekroczenia w badanej zlewni został wykorzystany model SWMM (Storm Water Management Model) w wersji 5.0.022, opracowany przez Agencję Ochrony Środowiska Stanów Zjednoczonych (U.S. Environmental Protection Agency EPA). Przykłady zastosowania tego modelu do analiz hydrologicznych można znaleźć w pracach Zawilskiego i Sakson [10], Warwick`a i Tadepalli [9], Jang`a i in. [4], Barco i in. [1]. Do ustalenia opadu efektywnego w przedstawianych analizach wybrano metodę CN-SCS [6], a do obliczenia transformacji fal wezbraniowych w kanałach zastosowano model fali dynamicznej [7].

Adaptacja modelu SWMM dla zlewni Potoku Służewieckiego polegała na utworzeniu w modelu obiektów, które reprezentują fizyczne składniki rzeczywistego systemu hydrologicznego i hydraulicznego zlewni, a następnie na określeniu wartości ich parametrów będących w większości przypadków fizycznie mierzalnymi charakterystykami (rys. 3). Model SWMM adaptowano dla trzech scenariuszy obliczeniowych, poprzez dostosowanie parametrów modelu do obliczenia przepływów o określonym prawdopodobieństwie. Model umożliwił wyznaczenie przepływów o prawdopodobieństwach $50 \%$ (scen. 1), 10\% (scen. 2) oraz 2 i 1\% (scen. 3). Pierwszą adaptację modelu dla badanej zlewni autor przeprowadził w 2009 r., publikując jej wyniki we wcześniejszej pracy [2]. W celu przeprowadzenia analiz, przedstawionych w niniejszej pracy, opracowano od podstaw model badanej zlewni.

Do oszacowania i identyfikacji parametrów obiektów modelu, wykorzystano pomierzone w terenie i zidentyfikowane na podstawie dostępnych opracowań charakterystyki rzeczywistych obiektów oraz wartości parametrów zalecane w tabelach podręcznika [5]. Obiekty, które uwzględniono w modelu zlewni:

- Dwa posterunki opadowe, które są zlokalizowane na obszarze lotniska „Okęcie" i kampusu SGGW w Warszawie.

- Obszary cząstkowe (3386 obszarów), które wydzielono w zlewni ze względu na charakter użytkowania i zmienną wielkość spływu z tych zlewni. Dla każdego obszaru cząstkowego określono wartości 13. parametrów, wykorzystywanych do obliczenia ilości spływu wód deszczowych.

- Kanały otwarte i przewody sieci kanalizacyjnej (2265 odcinków kanałów). Przekroje poprzeczne Potoku Służewieckiego na odcinku od km 0+000 do 6+576 oraz na całej długości Rowu Wolica uwzględniono w modelu na podstawie danych opracowanych przez firmę WAGA-BART.

- Przepusty drogowe i inne obiekty infrastruktury komunikacyjnej. Przepusty zlokalizowane w Potoku Służewieckim na odcinku od km 0+000 km do $6+576$ oraz w Rowie Wolica uwzględniono w modelu na podstawie danych firmy WAGA-BART.

- Zbiorniki powierzchniowe i zbiorniki zamknięte. Charakterystyki zbiorników zamkniętych na obszarze portu lotniczego „Okęcie” i ich urządzeń do regula- 
cji przepływu uwzględniono w modelu na podstawie dokumentacji powykonawczej.

- Klapy zwrotne w kanałach, urządzenia upustowe i przelewowe zbiorników, pompy i zastawki współpracujące ze zbiornikami.

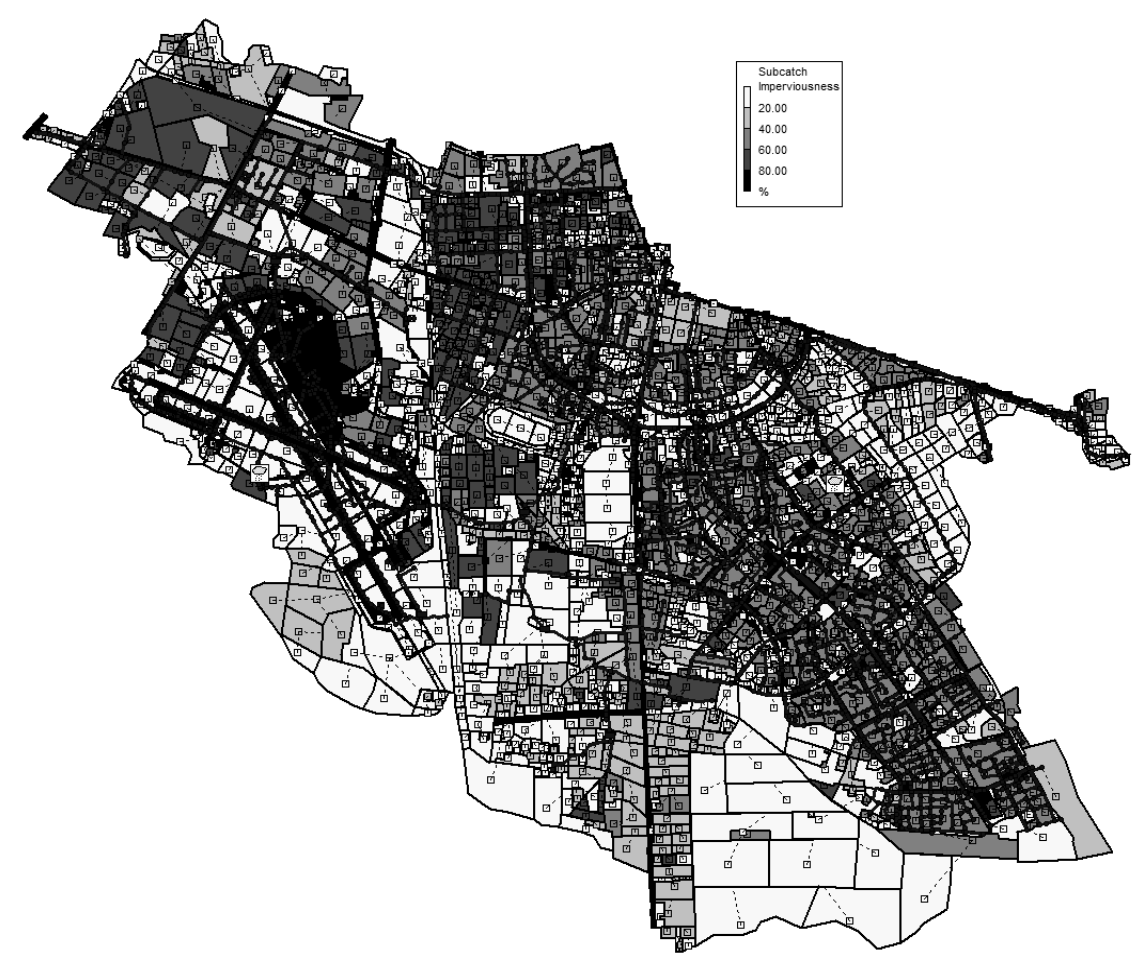

Rys. 3. Obszary cząstkowe i kanały na obszarze zlewni Potoku Służewieckiego w modelu SWMM

Fig. 3. Sub-areas and channels in the Służewiecki Stream catchment in the SWMM model

\section{Wyniki analiz}

\subsection{Obliczenie przepływów o określonych prawdopodobieństwach}

Wykorzystując model SWMM, adaptowany dla badanej zlewni, obliczono przepływy o prawdopodobieństwach przekroczenia 50, 10, 2 i 1\% (wywołanych opadami deszczu o tym samym prawdopodobieństwie) w 8. przekrojach Potoku Służewieckiego (przekroje I-V, VIII-X) oraz w 2. przekrojach Rowu Wolica (VI, VII), zlokalizowanych w charakterystycznych punktach tych cieków. Lokalizację przekrojów obliczeniowych przedstawiono na rys. 4. Do obliczenia wysokości opadów wykorzystano formułę zaproponowaną przez Bogdanowicz i Stachý’ego [3]. Przyjęto założenie o równomierności wysokości opadu w całej zlewni. 


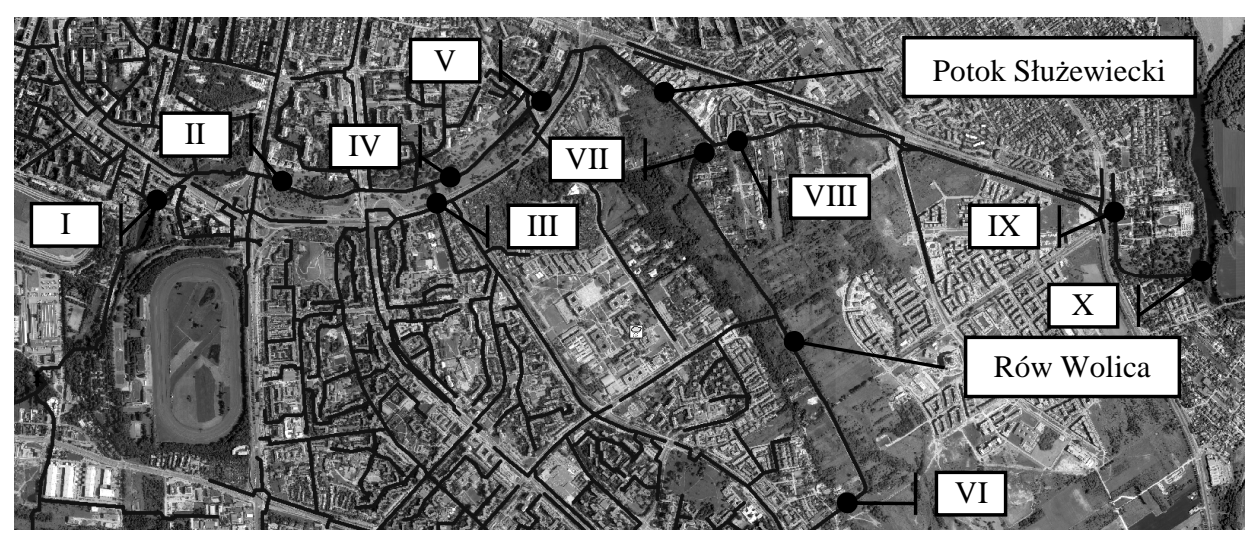

Rys. 4. Lokalizacja przekrojów obliczeniowych w badanej zlewni

Fig. 4. Location of calculation`s sections in the catchment

Skrajne przekroje obliczeniowe Potoku Służewieckiego, tj. I oraz X, znajdują się odpowiednio poniżej Stawu Wyścigi i w ujściu do Jez. Wilanowskiego. Przekrój numer II jest zlokalizowany poniżej „Stawu Służewieckiego”. Przekrój numer III znajduje się na wylocie kolektora deszczowego do Potoku, odwadniającego dolną część obszaru dzielnicy Ursynów. Poniżej wylotu tego kolektora znajduje się przekrój obliczeniowy numer IV. Przekroje VI-VII znajdują się w Rowie Wolica, odpowiednio poniżej wylotu kolektora deszczowego i powyżej ujścia cieku do Potoku Służewieckiego. Przekrój VIII jest usytuowany poniżej ujścia Rowu Wolica do Potoku.

W każdym z dziesięciu przekrojów obliczono przepływy maksymalne o prawdopodobieństwach 50,10, 2 i 1\%, które odpowiadają największej wartości przepływu kulminacyjnego hydrogramu, obliczonej w reakcji na opad o krytycznym czasie trwania i określonym prawdopodobieństwie. Charakterystyki opadów obliczeniowych oraz wartości prognozowanych przepływów i objętości wezbrań, które obliczono za pomocą modelu SWMM, zestawiono w tab. 1. Zmiany wartości przepływów o prawdopodobieństwach 50 i $2 \%$ dla 7. przekrojów obliczeniowych w Potoku Służewieckim (I-II, IV-V, VIII-X), zlokalizowanych na całej długości badanego odcinka Potoku, przedstawiono na rys. 5.

$\mathrm{Na}$ wartości przepływów w przekroju obliczeniowym numer I (na początku badanego odcinka Potoku) miały wpływ zbiorniki na obszarze lotniska „Okęcie", Staw Wyścigi oraz przepusty drogowe, zlokalizowane powyżej tego przekroju. W przekrojach II i IV obliczono znacznie większe przepływy niż w przekroju I. Gwałtowny wzrost przepływów w tych przekrojach jest spowodowany dopływem wód opadowych do Potoku Służewieckiego przez wyloty kanalizacji deszczowej. Przyczyną redukcji przepływów poniżej przekroju numer VIII jest transformacja przepływów w kanale, w której zasadnicze znaczenie ma wylewanie wód opadowych z koryta i redukcja przepływu przez przepusty drogowe. 
Tabela 1. Charakterystyki opadów obliczeniowych i wartości odpływu

Table 1. Characteristics of calculating`s rainfalls and values of outflow

\begin{tabular}{|c|c|c|c|c|c|c|c|}
\hline \multirow[t]{2}{*}{$\begin{array}{l}\text { Nazwa } \\
\text { kanału }\end{array}$} & \multirow[t]{2}{*}{$\begin{array}{c}\mathrm{Nr} \\
\text { prze- } \\
\text { kroju }\end{array}$} & $\begin{array}{l}\text { Kilome- } \\
\text { traż }\end{array}$ & Prawd. & $\begin{array}{l}\text { Krytyczny } \\
\text { czas trwa- } \\
\text { nia opadu }\end{array}$ & $\begin{array}{l}\text { Wysokość } \\
\text { opadu }\end{array}$ & $\begin{array}{l}\text { Przepływ } \\
\text { - SWMM }\end{array}$ & $\begin{array}{c}\text { Objętość } \\
\text { wezbrania }\end{array}$ \\
\hline & & {$[\mathrm{km}]$} & {$[\%]$} & [min] & {$[\mathrm{mm}]$} & {$\left[\mathrm{m}^{3} \cdot \mathrm{s}^{-1}\right]$} & [tys. $\left.\mathrm{m}^{3}\right]$ \\
\hline \multirow{8}{*}{ 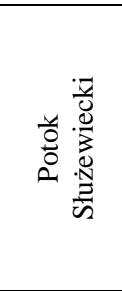 } & \multirow{4}{*}{ I } & \multirow{4}{*}{$6+576$} & 50 & 180 & 25,8 & 2,137 & 92,5 \\
\hline & & & 10 & 180 & 44,0 & 4,979 & 182,8 \\
\hline & & & 2 & $170^{\circ}$ & 56,7 & 5,702 & 234,6 \\
\hline & & & 1 & $170^{\circ}$ & 61,6 & $5,797^{-}$ & 247,3 \\
\hline & \multirow{4}{*}{ II } & \multirow{4}{*}{$5+900$} & 50 & 150 & 25,0 . & 6,981 & 165,3 \\
\hline & & & 10 & 150 & 42,9 & 12,348 & 320,4 \\
\hline & & & 2 & 150 & 55,8 & 15,860 & 431,1 \\
\hline & & & 1 & 150 & 60,6 & 16,802 & 465,9 \\
\hline \multirow{4}{*}{ Kolektor } & \multirow{4}{*}{ III } & \multirow{4}{*}{$4+978$} & 50 & 50 & 19,1 & 7,733 & 42,2 \\
\hline & & & 10 & 40. & 31,1 & 11,648 & 72,0 \\
\hline & & & 2 & 30 & 37,3 & 13,328 & 89,7 \\
\hline & & & 1 & $30^{\circ}$ & 40,6 & 13,924 & 99,1 \\
\hline \multirow{8}{*}{ 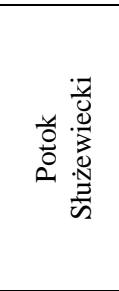 } & \multirow{4}{*}{ IV } & \multirow{4}{*}{$4+975$} & 50 & 110 & 23,5 & 13,345 & 215,1 \\
\hline & & & 10 & 120 & 41,5 & 22,451 & 428,0 \\
\hline & & & 2 & 150 & 55,8 & $27,807^{\circ}$ & 620,2 \\
\hline & & & 1 & 150 & 60,6 & $29,387^{-}$ & 677,3 \\
\hline & \multirow{4}{*}{ V } & \multirow{4}{*}{$4+267$} & 50 & 130 & 24,4 & 13,863 & 227,0 \\
\hline & & & 10 & 140 & 42,5 & 23,019 & 449,9 \\
\hline & & & 2 & 150 & 55,8 & $28,825^{\circ}$ & 631,2 \\
\hline & & & $\overline{1}$ & 150 & 60,6 & 30,500 & 691,2 \\
\hline \multirow{8}{*}{ 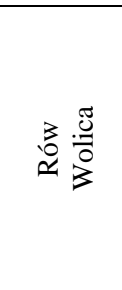 } & \multirow{4}{*}{ VI } & \multirow{4}{*}{$2+318$} & 50 & 80 & 21,7 & 8,005 & 48,9 \\
\hline & & & 10 & $80^{\circ}$ & 37,6 & 9,770 & 81,7 \\
\hline & & & 2 & $80^{-}$ & 49,0 & 11,958 & $110,4^{\circ}$ \\
\hline & & & 1 & 80 & 53,3 & 12,402 & 121,8 \\
\hline & \multirow{4}{*}{ VII } & \multirow{4}{*}{$0+000$} & 50 & 130 & 24,4 & 2,373 & $56,2$. \\
\hline & & & 10 & 130 & 42,0 & 4,080 & 102,4 \\
\hline & & & 2 & 160 & 56,2 & 5,563 & 166,1 \\
\hline & & & 1 & 160 & 61,1 & $5,759^{-}$ & 184,7 \\
\hline \multirow{12}{*}{ 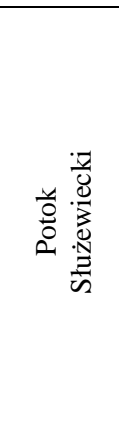 } & \multirow{4}{*}{ VIII } & \multirow{4}{*}{$2+951$} & 50 & 240 & 27,1 & 8,898 & 315,2 \\
\hline & & & 10 & 240 & 45,8 & $16,075^{\circ}$ & 603,9 \\
\hline & & & 2 & 170 & 56,7 & 20,902 & 782,8 \\
\hline & & & 1 & 120 & 58,8 & $20,907^{-}$ & 794,8 \\
\hline & & & 50 & 260 & 27,5 & 8,027 & 317,0 \\
\hline & IX & $0+726$ & 10 & 260 & 46,3 & $13,275^{\circ}$ & 575,8 \\
\hline & $1 X$ & $0+120$ & 2 & 240 & 59,3 & $18,025^{\circ}$ & 797,9 \\
\hline & & & 1 & 240 & 64,4 & $18,640^{-}$ & 851,7 \\
\hline & & & 50 & 260 & 27,5 & 7,811 & 315,7 \\
\hline & $X$ & $0+000$ & 10 & 260 & 46,3 & $13,075^{-}$ & 571,0 \\
\hline & $\lambda$ & $0+000$ & 2 & 240 & 59,3 & 17,833 & 793,6 \\
\hline & & & 1 & 240 & $64,4^{-}$ & $18,440^{\circ}$ & 854,1 \\
\hline & Wartość & inimalna & & 30 & 19,1 & 2,137 & 42,2 \\
\hline & Vartość & ksymalna & & 260 & 64,4 & 30,500 & 854,1 \\
\hline
\end{tabular}


Największe wartości przepływów maksymalnych hydrogramów prognozowano w Potoku Służewieckim w przekroju obliczeniowym numer V (km 4+267). Przepływy o określonym prawdopodobieństwie przekroczenia, obliczone za pomocą modelu SWMM, wynoszą: $\mathrm{Q}_{50 \%}=13,863, \mathrm{Q}_{10 \%}=23,019, \mathrm{Q}_{2 \%}=28,825$ i $\mathrm{Q}_{1 \%}=30,500 \mathrm{~m}^{3} \cdot \mathrm{s}^{-1}$. Objętości, które obliczono dla hydrogramów prognozowanych $\mathrm{w}$ różnych przekrojach, zawierały się $\mathrm{w}$ granicach od 42,2 tys. $\mathrm{m}^{3}$ do 854,1 tys. $\mathrm{m}^{3}$. Największe objętości wezbrań prognozowano w przekrojach VIII$\mathrm{X}$ Potoku Służewieckiego, zlokalizowanych poniżej ujścia Rowu Wolica.

Na odcinku Potoku Służewieckiego od km 3+875 do 0+000 (od ul. Dolinka Służewiecka - zlokalizowanej ok. $400 \mathrm{~m}$ poniżej przekroju V, do ujścia w Jez. Wilanowskim) występuje największe zagrożenie powodziowe. Przepustowość Potoku na tym odcinku kształtuje się na poziomie przepływu maksymalnego o prawdopodobieństwie 50\%. Biorąc pod uwagę zagospodarowanie tego terenu - zabudowa mieszkaniowa jednorodzinna i wielorodzinna wzdłuż ul. Arbuzowej i Wilanowskiej, oraz Muzeum Pałacu w Wilanowie, jest to wielkość stanowczo za mała. Wyznaczony obszar, który może ulec podtopieniu w wyniku wystąpienia przepływów o prawdopodobieństwie $1 \%$, wynosi $1,6 \mathrm{~km}^{2}$.

Duży wpływ na zwiększenie zagrożenia powodziowego w dolnym biegu Potoku Służewieckiego ma dopływ wód opadowych Rowem Wolica. Wartości przepływów w górnym odcinku Rowu Wolica (w przekroju VI, zlokalizowanym poniżej wylotu kolektora) zawierały się $\mathrm{w}$ granicach od 8,005 do $12,402 \mathrm{~m}^{3} \cdot \mathrm{s}^{-1}$, w zależności od prawdopodobieństwa wystąpienia opadu obliczeniowego.

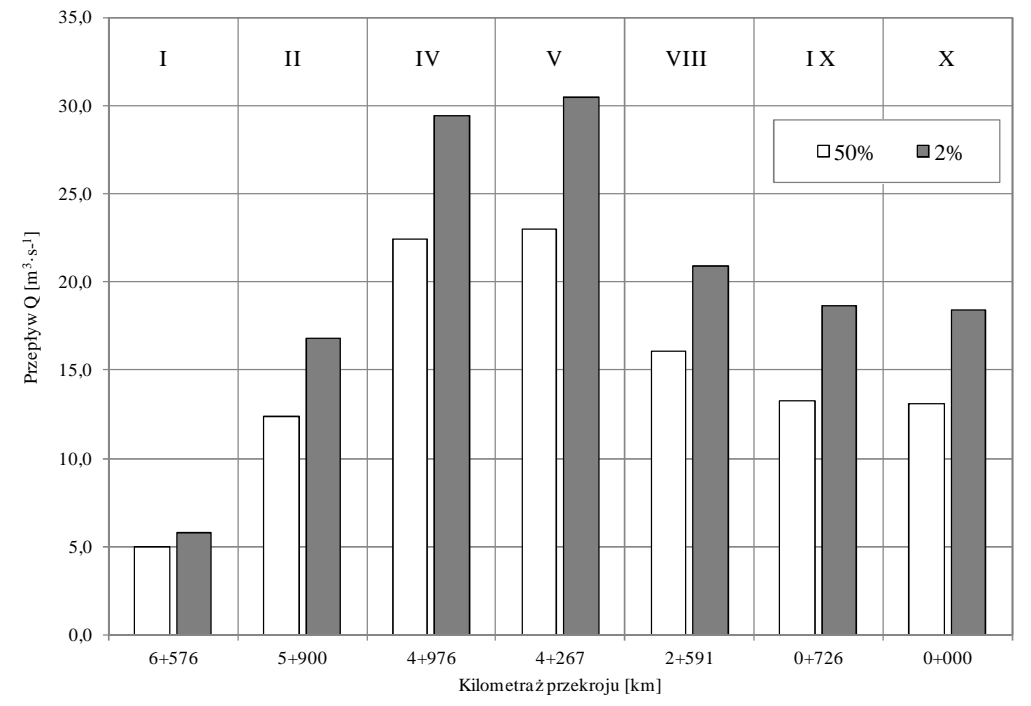

Rys. 5. Wartości przepływów maksymalnych w przekrojach Potoku Służewieckiego

Fig. 5. Values of maximum flows in sections of the Służewiecki Stream 


\subsection{Redukcja przepływów przez zastosowanie kryzy w kolektorze}

Wyniki analiz wskazują, że jedną z przyczyn występowania zagrożenia powodziowego w dolnym biegu Potoku Służewieckiego jest dopływ dużej ilości wód opadowych Rowem Wolica. W celu określenia możliwości redukcji przepływów w Rowie Wolica (zasilanym wodami opadowymi odprowadzanymi za pomocą kolektora ze zlewni o powierzchni $6,23 \mathrm{~km}^{2}$ ), przeprowadzono obliczenia w których uwzględniono zastosowanie kryzy (zwężki) na odcinku ujściowym kolektora do kanału otwartego. Obliczenia przeprowadzono za pomocą modelu SWMM, dla przepływów o prawdopodobieństwach 50, 10 i $2 \%$.

Analizy polegały na przyjmowaniu do obliczeń kolejnych coraz mniejszych średnic kryzy, którą usytuowano w kolektorze (w miejscu znajdującym się ok. 250 m powyżej wylotu kolektora do Rowu Wolica - rys. 6), aż do momentu uzyskania największej redukcji przepływów poniżej kryzy przy jednoczesnym spełnieniu założonego kryterium: maksymalne wzniesienie zwierciadła wody w punktach węzłowych sieci kanalizacyjnej na obszarze zlewni Rowu Wolica, wywołane ograniczeniem przepływu przez kryzę, nie może przekroczyć poziomu $0,3 \mathrm{~m}$ od powierzchni terenu $\mathrm{w}$ każdym punkcie węzłowym modelu (odpowiadającym w rzeczywistości studzience kanalizacyjnej).

Ustalone na podstawie analiz $\mathrm{w}$ modelu średnice kryzy $\mathrm{w}$ przewodzie kolektora, w odniesieniu do przepływów o określonym prawdopodobieństwie wystąpienia, zestawiono w tab. 2 (średnica kolektora wynosi $\phi 2,00 \mathrm{~m}$ ). W tabeli zamieszczono również wartości przepływów, prognozowanych w przekroju VI w Rowie Wolica (poniżej wylotu kolektora) dla scenariuszy bez zastosowania kryzy oraz z kryzą w kolektorze. Analiza wykazała, że zastosowanie kryzy w kolektorze pozwoli zredukować przepływy kulminacyjne wezbrania o prawdopodobieństwach 50, 10 i $2 \%$ odpowiednio o 61,0, 46,0 i 36,6\%. Zastosowanie kryzy o stałej średnicy $\phi 1,08 \mathrm{~m}$, ustalonej dla przepływu o prawdopodobieństwie $2 \%$, spowoduje znacznie mniejszą redukcję przepływów maksymalnych o prawdopodobieństwach 50 i $10 \%$.

Tabela 2. Średnice kryzy w kolektorze i przepływy maksymalne dla różnych scenariuszy

Table 2. Diameters of the orifice in the collector and maximum flows for different scenarios

\begin{tabular}{|c|c|c|c|c|c|}
\hline $\begin{array}{l}\text { Prawdopo- } \\
\text { dobieństwo }\end{array}$ & $\begin{array}{c}\text { Średnica } \\
\text { kryzy }\end{array}$ & $\begin{array}{l}\text { Przepływ } \\
\text { bez kryzy }\end{array}$ & $\begin{array}{c}\text { Przepływ } \\
\text { z kryzą }\end{array}$ & $\begin{array}{l}\text { Redukcja } \\
\text { przepływu }\end{array}$ & $\begin{array}{c}\text { Przepływ } \\
\text { z kryzą } \\
\phi 1,08 \text { m }\end{array}$ \\
\hline$[\%]$ & [m] & {$\left[\mathrm{m}^{3} \cdot \mathrm{s}^{-1}\right]$} & {$\left[\mathrm{m}^{3} \cdot \mathrm{s}^{-1}\right]$} & {$[\%]$} & {$\left[\mathrm{m}^{3} \cdot \mathrm{s}^{-1}\right]$} \\
\hline 50 & 0,66 & 8,005 & 3,120 & $-61,0$ & 6,530 \\
\hline 10 & 0,88 & 9,770 & 5,280 & $-46,0$ & 6,980 \\
\hline 2 & 1,08 & 11,958 & 7,580 & $-36,6$ & 7,580 \\
\hline
\end{tabular}

Przeprowadzono również obliczenia, mające na celu ustalenie możliwości redukcji przepływów o prawdopodobieństwach 50, 10 i $2 \%$ w przekroju 
obliczeniowym III, poprzez zastosowanie kryzy na odcinku ujściowym kolektora do Potoku Służewieckiego (lokalizację przekroju III pokazano na rys. 4). Analizy wykazały, że nawet niewielkie ograniczenie przepływu przez kryzę spowoduje spiętrzenie wody w niektórych węzłach kanalizacyjnych, skutkujące podtopieniami na obszarze zlewni cząstkowej, obejmującym dzielnicę Ursynów. Oznacza to brak możliwości redukcji przepływów w przekroju III przez zastosowanie kryzy.

Przykładowe hydrogramy w przekroju VI Rowu Wolica, prognozowane w reakcji na opad o prawdopodobieństwie $10 \%$ dla scenariuszy z zastosowaniem kryzy i bez kryzy, przedstawiono na rys. 7. Zastosowanie kryzy spowodowało redukcję przepływu kulminacyjnego wezbrania i zmianę rozkładu odpływu w czasie. Natomiast na rys. 8-9 zamieszczono profile kolektorów w ulicach Płaskowicka i Rosoła (ich lokalizację pokazano na rys. 6), przedstawiające maksymalne położenie zwierciadła wody w studzienkach kanalizacyjnych przy scenariuszu zakładającym zastosowanie kryzy, w reakcji na opad o prawdopodobieństwie $10 \%$.

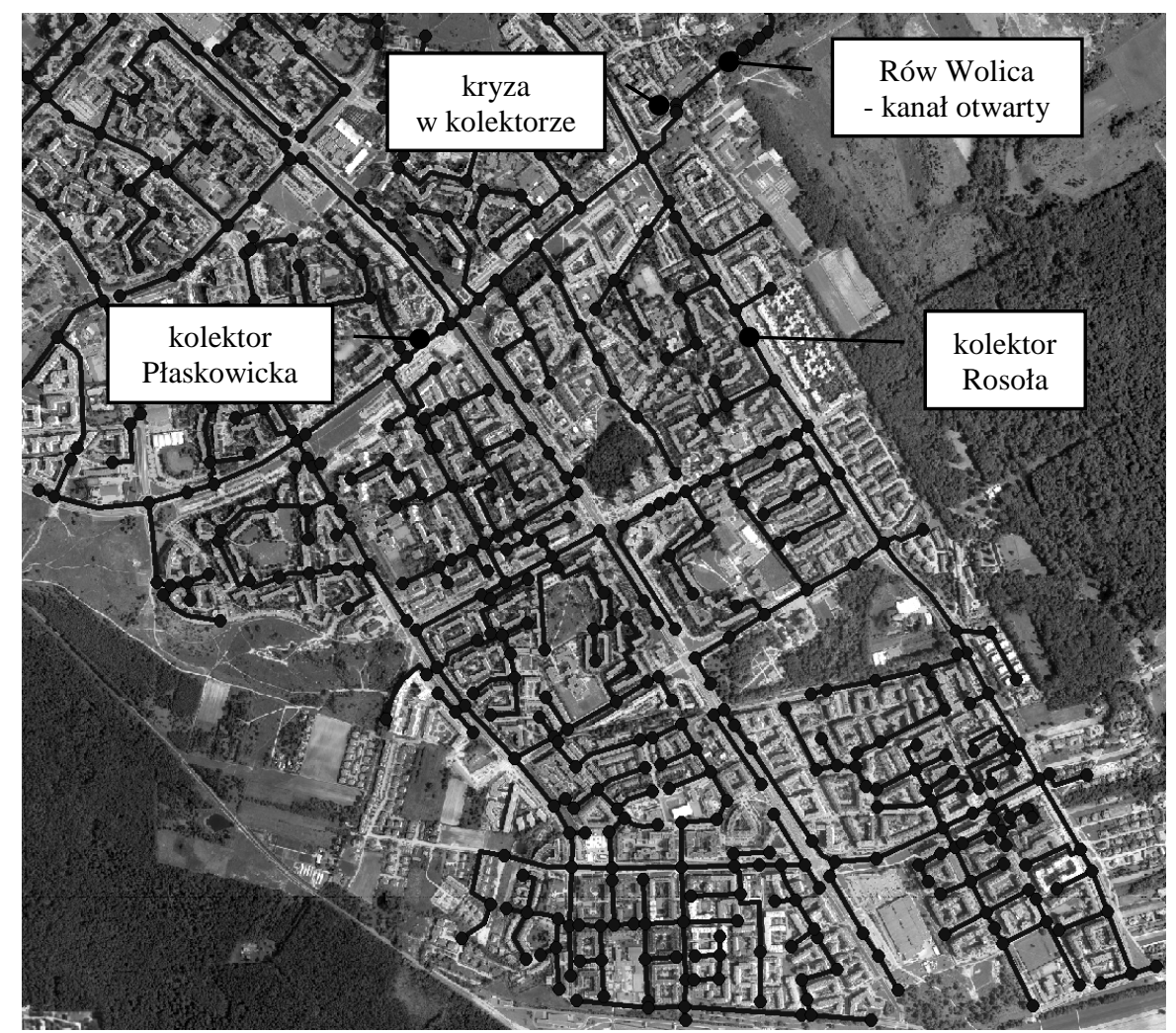

Rys. 6. Kanalizacja deszczowa w zlewni Rowu Wolica oraz lokalizacja kryzy w kolektorze

Fig. 6. Storm sewer system in the Wolica Ditch catchment and location of the orifice in collector 


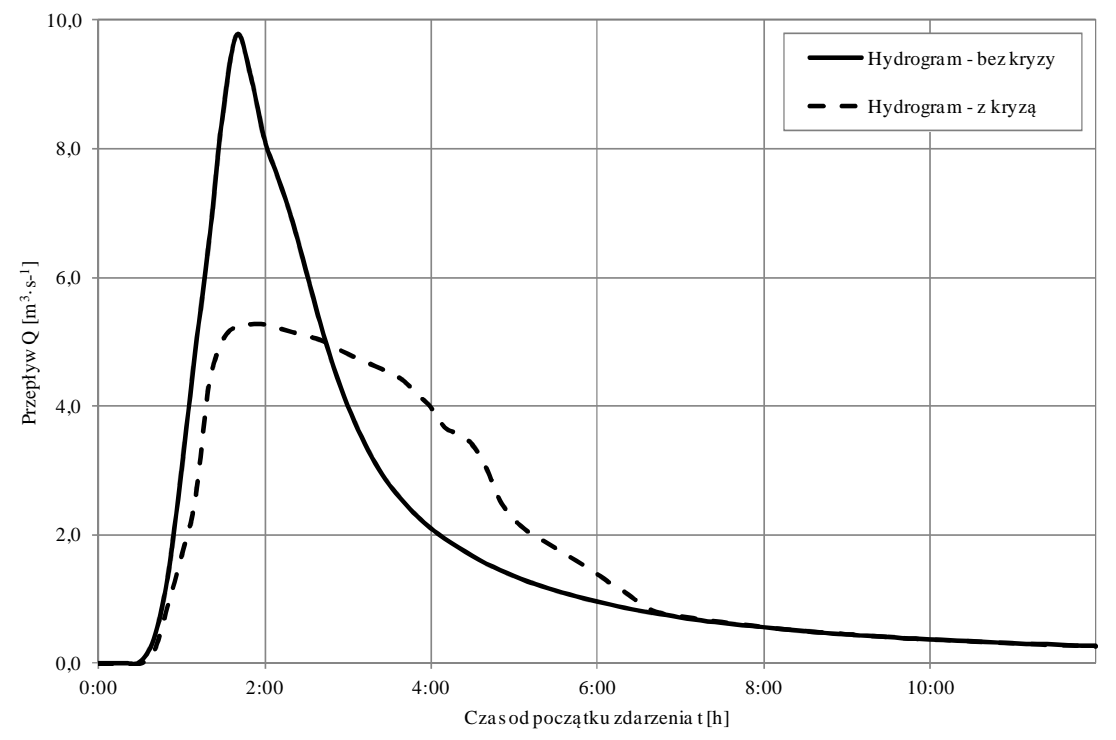

Rys. 7. Hydrogramy obliczone w przekroju VI dla scenariuszy z kryzą i bez kryzy Fig. 7. Hydrographs calculated in the section VI for scenarios with the orifice and without orifice

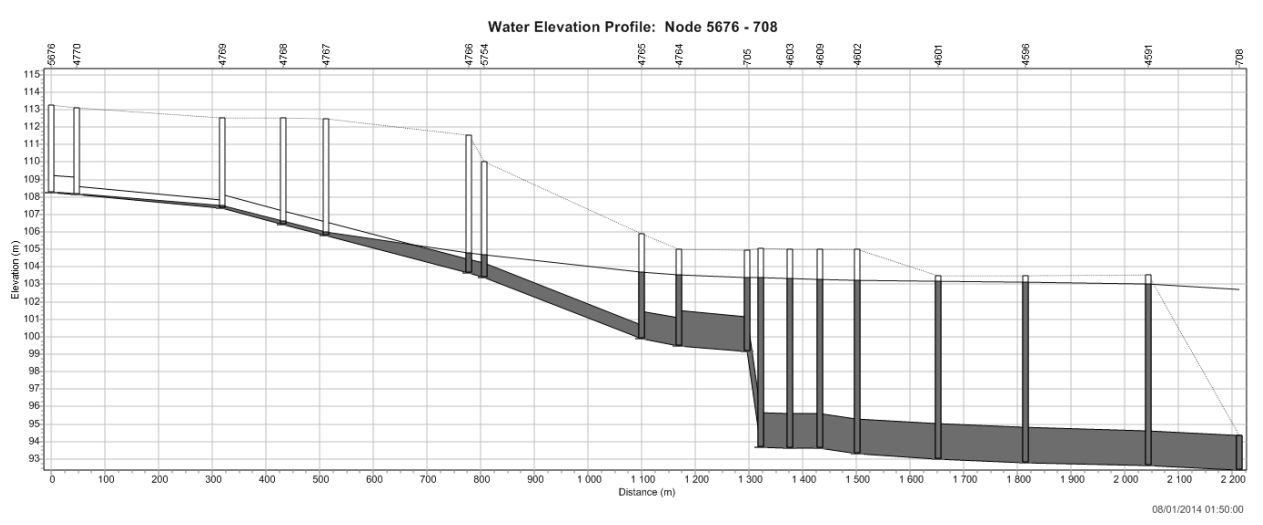

Rys. 8. Maksymalny poziom wody w kolektorze w ulicy Płaskowickiej - scen. z kryzą $(\mathrm{p}=10 \%)$

Fig. 8. The maximum water level in the collector in the Płaskowicka - scenario with the orifice 


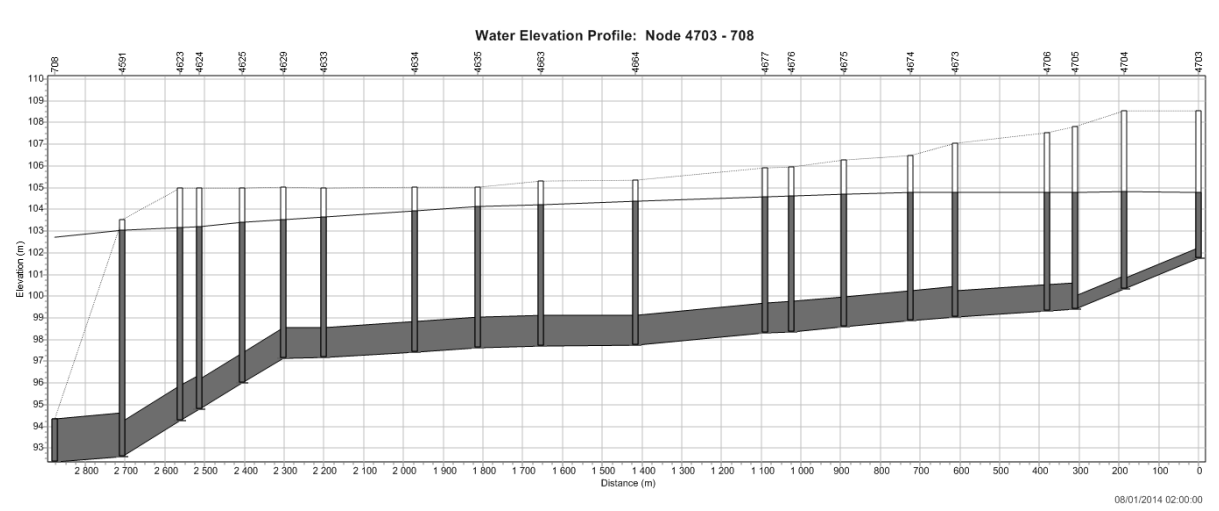

Rys. 9. Maksymalny poziom wody w kolektorze w ulicy Rosoła - scen. $z$ kryzą $(p=10 \%)$

Fig. 9. The maximum water level in the collector in the Rosoła st. - scenario with the orifice

\section{Wnioski}

- Największe wartości przepływów prognozowano w Potoku Służewieckim w przekroju obliczeniowym numer V (km 4+267). Przepływy o określonym prawdopodobieństwie przekroczenia, obliczone za pomocą modelu SWMM, wynoszą: $\mathrm{Q}_{50 \%}=13,863, \mathrm{Q}_{10 \%}=23,019, \mathrm{Q}_{2 \%}=28,825 \mathrm{i} \mathrm{Q} \mathrm{Q}_{1 \%}=30,500 \mathrm{~m}^{3} \cdot \mathrm{s}^{-1}$.

- Objętości wezbrań, prognozowanych w Potoku Służewieckim i Rowie Wolica, wynosiły od 42,2 tys. $\mathrm{m}^{3}$ do 854,1 tys. $\mathrm{m}^{3}$. Największe wartości objętości obliczono dla wezbrań w przekrojach VIII-X Potoku Służewieckiego, zlokalizowanych poniżej ujścia Rowu Wolica.

- W przekrojach II-V obliczono znacznie większe przepływy niż w przekroju I, zlokalizowanym na początku analizowanego odcinka Potoku Służewieckiego. Gwałtowny wzrost przepływów w tych przekrojach jest spowodowany dopływem wód opadowych do Potoku Służewieckiego poprzez kolektory. Przepływy w przekroju III (w kolektorze odwadniającym część dzielnicy Ursynów) są tego samego rzędu wielkości jak przepływy prognozowane w profilu II.

- Przyczyną redukcji przepływów w Potoku Służewieckim poniżej przekroju VIII jest wylewanie wód opadowych z koryta i ograniczenie przepustowości przez przepusty drogowe.

- Największe zagrożenie powodziowe występuję na odcinku Potoku Służewieckiego od km 3+875 do 0+000 (poniżej przekroju V). Przepustowość koryta Potoku na tym odcinku kształtuje się na poziomie przepływu maksymalnego o prawdopodobieństwie 50\%. Biorąc pod uwagę zagospodarowanie przyległego terenu, jest to wielkość stanowczo za mała.

- Duży wpływ na zwiększenie zagrożenia powodziowego w dolnym biegu Potoku Służewieckiego ma dopływ wód opadowych Rowem Wolica. Wartości 
przepływów w górnym odcinku Rowu Wolica (w przekroju VI) zawierały się w granicach od 8,005 do $12,402 \mathrm{~m}^{3} \cdot \mathrm{s}^{-1}$, w zależności od prawdopodobieństwa wystąpienia opadu obliczeniowego.

- Zastosowanie kryzy na odcinku ujściowym kolektora do kanału otwartego Rowu Wolica (powyżej przekroju VI), pozwoli zredukować przepływy kulminacyjne wezbrania o prawdopodobieństwach 50,10 i 2\% odpowiednio o 61,0, 46,0 i 36,6\%. Zastosowanie kryzy o stałej średnicy $\phi 1,08 \mathrm{~m}$, ustalonej dla przepływu o prawdopodobieństwie $2 \%$, spowoduje znacznie mniejszą redukcję przepływów maksymalnych o prawdopodobieństwach 50 i $10 \%$.

- Nawet niewielkie ograniczenie przepływu przez kryzę umieszczoną w przekroju III (w kolektorze odwadniającym część dzielnicy Ursynów) spowoduje spiętrzenie wody w niektórych studzienkach kanalizacyjnych, skutkujące podtopieniami na obszarze zlewni cząstkowej.

\section{Literatura}

[1] Barco J., Wong K.M., Stenstrom M.K.: Automatic calibration of the U.S. EPA SWMM model for a large urban catchment, J. Hydraul. Eng. 134(4), 2008, s. $466-474$.

[2] Barszcz M.: Prognoza maksymalnych przepływów prawdopodobnych wywołanych ulewami w zurbanizowanej zlewni Potoku Służewieckiego, Przegląd Naukowy Inżynieria i Kształtowanie Środowiska, Vol. 4(46), 2009, s. 3-23.

[3] Bogdanowicz E., Stachý J.: Maksymalne opady deszczu w Polsce, charakterystyki projektowe, Materiały badawcze IMGW 23, Hydrologia i Oceanologia 85, 1997.

[4] Jang S., Cho M., Yoon Y., Kim S., Kim G., Kim L., Aksoy H.: Using SWMM as a tool for hydrologic impact assessment, Desalination 212, 2007, s. 344-356.

[5] Rossman L.A.: Storm water management model user`s manual version 5.0, National Risk Management Research Laboratory, U.S. Environmental Protection Agency, Cincinnati, OH 2010.

[6] SCS (Soil Conservation Service): Urban Hydrology for Small Watersheds, Technical Release 55, Soil Conservation Service, Washington, D.C 1986.

[7] Szymkiewicz R.: Modelowanie matematyczne przepływów w rzekach i kanałach, Wydawnictwo Naukowe PWN, Warszawa 2000.

[8] WAGA-BART: Koncepcja „Przebudowa układu hydrologicznego obejmującego Potok Służewiecki i Rów Wolica w celu zabezpieczenia przeciwpowodziowego rejonu dolnego biegu Potoku Służewieckiego. Etap II”, Waga-Bart, Warszawa 2014.

[9] Warwick J.J., Tadepalli P.: Efficacy of SWMM application, J. Water Resour. Plan. Manage, 117, 1991, s. 352-366.

[10] Zawilski M., Sakson G.: Wykorzystanie programu SWMM w modelowaniu systemów kanalizacyjnych, Materiały konferencyjne (red. Łomotowski) „Problemy zagospodarowania wód opadowych", Wydawnictwo Seidel-Przywecki Sp. z o.o., Warszawa, 2008, s. 155-169. 


\section{THE CALCULATION OF MAXIMUM FLOWS AND THEIR REDUCTION IN URBANIZED CATCHMENT}

\section{S u m m a r y}

The article presents the results of an application of the SWMM model to calculating flows with probability of exceedance of 50,10, 2 and $1 \%$ in eight profiles of the Służewiecki Stream on the section from $\mathrm{km} 0+000$ to $6+576$ as well in two profiles of Wolica Ditch. The Służewiecki Stream catchment in located in the southern part of Warsaw. The greatest flood hazard occurs on the section of the Służewiecki Stream from km $0+000$ to $3+875$. The capacity of the Służewiecki Stream in this section stands at a maximum flow with probability of $50 \%$. The highest values of flows in the Służewiecki Stream predicted in the calculation cross-section number V (km 4+267): $\mathrm{Q}_{50 \%}=13.863, \mathrm{Q}_{10 \%}=23.019, \mathrm{Q}_{2 \%}=28.825 \mathrm{i} \mathrm{Q} \mathrm{Q}_{1 \%}=30.500 \mathrm{~m}^{3} \cdot \mathrm{s}^{-1}$. One of reasons of occurrence of the flood hazard in lower part of the Służewiecki Stream is inflow of large amount of storm water by Wolica Ditch. The values of flows in the upper part of the Wolica Ditch (in the cross-section VI) ranged from 8,005 to $12,402 \mathrm{~m}^{3} \cdot \mathrm{s}^{-1}$, depending on the probability of rainfall. In order to identify opportunities for reduction of flows in the Wolica Ditch, calculations were carried out which included the application of a orifice in a collector located above open channel. The application of the orifice in the collector can reduce flows with probability of exceedance of 50,10 and 1\%, respectively by $61.0,46.0$ and $36.6 \%$. The application of the orifice with constant diameter of $\phi 1.08 \mathrm{~m}$, determined for the flow with probability of $2 \%$, will result in a much smaller reduction of maximum flows with probability of 50 and $10 \%$.

Keywords: urbanized catchment, SWMM model, maximum flows, flood hazard, orifice, reduction of flows

Przestano do redakcji: $30.08 .2015 \mathrm{r}$.

Przyjęto do druku: 1.03 .2016 r.

DOI: $10.7862 /$ rb.2016.105 